JEL L83, M31

\title{
FEATURES OF THE USE OF THE MARKETING COMPLEX AND ITS CONCEPTS AT THE ENTERPRISES OF THE HOTEL INDUSTRY
}

\author{
Iryna Kyryliuk, Oksana Lytvyn
}

\begin{abstract}
The article reveals the importance of marketing for the enterprises of the hotel industry, features of the use of its concepts are investigated. The practical marketing of the hotel product is analyzed as well as tasks of the practical marketing in the hotel industry are determined. The problems that arise during the implementation of the marketing complex are studied, ways of their solution are proposed. The directions to increase the efficiency of marketing by introducing new innovative methods of influence on the consumers of hotel services are determined.

Keywords: marketing, lateral marketing, marketing complex, marketing concept, marketing management, marketing system, hotel enterprise.

УДК 338.48:339.138

\section{ОСОБЛИВОСТІ ВИКОРИСТАННЯ КОМПЛЕКСУ МАРКЕТИНГУ ТА ЙОГО КОНЦЕПЦІЙ НА ПІДПРИЕМСТВАХ ГОТЕЛЬНОГО БІЗНЕСУ}

\author{
Кирилюк І. М., Литвин О. В.
}

\begin{abstract}
Анотація. Посилення конкуренції в готельній галузі збільшує актуальність пошуку шляхів забезпечення конкурентоспроможності підприємств шляхом застосування більш ефективних методів управління. Основним завданням дослідження $\epsilon$ аналіз застосування маркетингу та реалізації його концепцій у готельній індустрії, а також обгрунтування пропозицій щодо вдосконалення. У статті розкрито значення маркетингу для підприємств готельного господарства, досліджено особливості використання його концепцій. Проаналізовано практичний маркетинг готельного продукту та визначено його завдання в готельної індустрії. Окреслено проблеми, що виникають при впровадженні комплексу маркетингу, запропоновано шляхи їх вирішення. Визначено напрями підвищення ефективності маркетингу шляхом впровадження нових інноваційних методів впливу на споживачів готельних послуг. Маркетинг у готельній індустрії має певні особливості, пов'язані зі специфікою готельної індустрії. Методи маркетингових досліджень, їх функції, завдання та елементи маркетингової системи, що використовуються в готельній індустрії, повинні враховувати особливості готельної галузі. Підприємства готельного бізнесу в сучасних умовах управління не можуть досягти поставлених цілей і пріоритетів, бути конкурентоспроможними та ефективно працювати без активного використання маркетингу та реалізації його концепцій. Впровадження інноваційних маркетингових методів забезпечить високий рівень рентабельності готелю в конкурентному середовищі, формування відповідного іміджу, задоволення вимог клієнтів щодо обсягу, структури та якості послуг, а також створить умови для стабільного ведення бізнесу, комплексного вирішення комерційних, організаційних та соціальних проблем готельної компанії.
\end{abstract}

Ключові слова: маркетинг, латеральний маркетинг, комплекс маркетингу, концепція маркетингу, маркетингове управління, система маркетингу, готельне підприємство. 
The problem's setting. The growth of competition in the hotel industry increases the relevance of finding ways to ensure the competitiveness of enterprises through the application of more effective methods of managing. Competition prompts to seek and find more modified tools for the formation of competitive advantages of organizations in the non-productive sphere. The results enable them to meet equally important secondary needs. In a context of fierce competition and consumer sensitivity to the price of products, an important element of the successful development of the hotel industry is the development and implementation of an effective marketing communication package.

The analyses of resent publications on the theme. Questions of the essence and effective use of the complex marketing were studied and revealed by many native and foreign researchers. The following researchers have made a significant contribution to the development of theoretical and methodological aspects of marketing and its concepts: G. Bagiyev, J. Burnet, E. Golubkov, T. Dibrova, P. Drucker, L. Ivanova, F. Kotler, O. Morgun, T. Primak, S. Skibinsky and others.

The aim of the article. The main objective of the study is to analyze the application of marketing and implementation of its concepts in the hotel industry and justify proposals for improvement.

The main results and its grounding. The market for hotel services has a rather complicated structure, because it intertwines both internal and external connections, it is an open system where its elements are interacting with the external environment. There are several areas of marketing activity, which, as a rule, are adapted including the specifics of the activities of hotel industry enterprises.
First and foremost, this is the practice of developing and improving the product, which is the key to the success of the hotel industry. Marketing is focused on solvency of the client. Therefore, the ability to identify and satisfy the needs of consumers is the main prerequisite for achieving the goals associated with profit generation, penetration into new markets, and the development of the enterprise. Modern marketing, according to many researchers, should be considered as one of the most important economic phenomena.

An explanatory dictionary defines the concept of "marketing" as a set of actions and its purpose is to persuade buyers to purchase products of the firm. Marketing includes activities for the distribution and promotion of products. In addition, it involves studying of the market in order to determine the likely reaction of the buyer to the planned production of new products and to determine if it is possible to enhance the attractiveness of products already produced, by modifying them [3, p. 348].

P. Drucker notes that the deprivation of sales from efforts to sell the product is the basis of the purpose of marketing. Effective marketing assumes that the product will sell itself. For this purpose, there will be no need for the efforts of sellers or promoters, since marketers must understand precisely the psychology and needs of buyers. Consequently, go directly for the purchase of this particular product [2].

Marketing in the hotel industry is a science and a system of practical measures related to the establishment of production and sales activities by business entities. It includes the processes of analysis of demand in the market of hotel services in order to identify the basic needs of consumers and the formation of a system for delecta- 
tion of these needs for the service placement for profit [1].

The practical marketing of the hotel product is aimed at fulfilling the following tasks of the hotel industry:

- substantiation of the need to provide hotel services by identifying existing or potential demand for them;

- organization of research works on development of design tours or other services that meet the needs of clients;

- coordination and planning of the organizational marketing strategy for the promotion and sale of hotel products and financial activities of hotels;

- improvement of methods of marketing strategy for sale of hotel product and promotion at the market;

- regulation and direction of all hotel activities to achieve general business goals.

To organize the effective activity of the enterprise and achieve the set goals, we need to get an appropriate tool, that is a set of methods and methods by which it would be possible to influence consumers and other subjects of the marketing system.

It is worth saying that nowadays there is the over-saturation of the goods and services market, reducing the purchasing power of the population. The primary task of marketers is searching and implementing original ideas that will provide the company with significant competitive advantages.

The effectiveness of traditional marketing technologies is beginning to decline. Therefore, the gradual abandonment from stereotypes leads to the search of new innovative methods to influence consumers, that means induces of using a creative strategy, which is a non-standard direction of the company's activity, which allows the optimal and effective way to achieve the goals. It is the creative approach allowing an enterprise to achieve greater market success and to identify itself in a competitive environment.

One of the tools of the creative strategy is a lateral marketing. Lateral marketing in translation means "lateral" (Latin lateral - sideways, latus - side) and it is a system of views and approaches based on associative logic that changes the perceptions of traditional, direct methods of business promotion. The task of lateral marketing is the deviation from the traditional methods of competition.

Lateral marketing is a new system of views that complements the traditional marketing with new opportunities for creating innovative ideas and organizes the process of creative thinking. This innovation gives the company an undeniable advantage over its competitors.

For applying this type of marketing, we need to use a creative and intuitive thinking. It is necessary for developing the creativity of the company's employees and for joying the marketing departments of extraordinary personalities. The difference between the lateral and the vertical thinking is significant, but there is no contradiction between them. On the contrary, both of these types of thinking are supplement and reinforce each other: the lateral thinking is increasing the efficiency of the vertical thinking the way of increasing the number of possible alternatives and vertically fails the ideas that generate lateral thinking, and finds them practical use.

The lateral approach encourages thinking widely. This is an innovative approach. Consequently, a new product will appear. Creating innovations in lateral marketing should be considered at three levels: - the level of the goods themselves; 
- the market level;

- the marketing mix level (at the level of the marketing complex).

At the level of the product, its innovation and change don't involve the changing of product or its service, but the method of its using means the time, place, method or situation of application of the product, or service that is changing. Lateral marketing at the market level involves searching for a demand that would satisfy a new innovative product. The level of marketing mix is based on changes in commodity policy and pricing, marketing, and communications policies [9].

Marketing in the field of hotel and restaurant business is the final concept of the cycle of the hotel business industry, which includes:

- work with the market for the exchange, including the search for buyers;

- definition of their needs;

- planning the relevant products of the hotel business and selling them;

- transportation of tourists to the place of consumption;

- pricing;

- organization of the service;

- advertising in order to meet the recreational needs and demands of consumers.

Marketing mix is very important within the overall marketing approach where hotels are developing partial strategies for all major elements of a marketing mix:

- product strategy;

- pricing strategy;

- pushing strategy;

- distribution strategy.

The product strategy involves the development of hotel services that are most relevant for users of hotel services, the development and introduction of new hotel services in the market.
The pricing strategy involves determining the behavior of the hotel on the market in terms of long-term prospects and pricing tactics for a specific period in relation to each of hotel service as well as a specific segment of the market.

The push strategy determines the purposeful activity of the hotel companies to disseminate positive information about themselves and their services. This activity includes advertising, sales promotion, publicity, public relations, participation in exhibition events, etc.

Distribution strategy includes the definition of channels, forms and methods of bringing hotel services to the consumer. It should be noted that in the last decade, along with traditional channels of distribution, new forms of internal structures of the channel are developing. One of the most significant events in the development of distribution channels is the emergence of vertical marketing systems, which include such an important component as franchising organizations [8].

The main task of marketing in the field of hotel and restaurant business is a help for their client in evaluating the company and its product.

By planning its activities, the hotel chooses an orientation towards the most acceptable marketing concept for itself. Correct development of the concept of hotel and restaurant business and implementation of its development strategy is a guarantee of successful business activity and gives the opportunity to become the most favorite institution for recreation for consumers of services rendered.

The concept of improving production implies that the hotel will try to make its services more affordable by distributing its services and reducing costs. However, it can make a negative effect on the results of 
its activities, if a hotel does not pay attention to work with customers.

The concept of improvement of goods (services) is aimed at focusing the main components of the hotel business marketing complex at the continuous improvement of the quality of service provision by improving them. In this case, the hotel often overlooks the real needs of the client who may be interested in comfortable living at an affordable price and is not ready to pay for additional services, while it often has alternative options to meet clients' needs.

The concept of intensification of commercial efforts is aimed at measures to stimulate the marketing of its services. Hotel companies spend a lot of money on propaganda, advertising companies, and more when they are focusing on this concept.

The concept of general (classical) marketing suggests that the focus of the enterprises of the hotel industry is monitoring on the state of the target market, identifies the needs of customers and conducts a set of marketing measures to meet these needs.

The concept of social and ethical marketing is aimed at identifying and satisfying the needs of the hotel. At the same time, the satisfaction of the society's interests as a whole should play a key role. It will form a positive image of the hotel and provide it with positive results of the activity.

Skilled management of customer relations is the basis for the interaction of consumer services enterprises to create and maintain the unique competitive advantage of enterprises. The process of customer relationship management in the organization includes:

- identify the most profitable or poten- tially profitable clients for further interaction;

- understand their needs and purchase interests;

- interact with clients to meet all their expectations.

Customer orientation includes the ability to manage all interaction channels where customers are connected with the enterprise. Most of these technologies in the process of customer relationship management at the enterprise focus on the implementation of marketing functions. Their most important directions are:

- sales management (increasing the efficiency of the distribution process, improving customer service);

- marketing planning (collecting and analyzing information about marketing actions, which serves as the basis for their effective planning; includes modeling of consumer behavior used for market segmentation);

- contact with clients (represented by the contact center responsible for the whole process of communication);

- service in the process of implementation (selection and assembly, reliability);

- pre-sale service maintenance (advertising, demonstrations, consultations);

- after-sales service (aimed at maintaining relationships with customers and seeking their satisfaction and changing needs - these actions mainly increase customer satisfaction);

- customer service (includes requirements for registration, monitoring and customer management services) $[10$, p. $802-$ 803].

The concept of marketing of mutual relations involves the establishment at the market between entities of relations that allow parallel or consistent implementation 
of goals, interests of equal parties and enter into mutually beneficial cooperation.

One of the main indicators of the hotel's competitive advantages is loyalty to the consumer, so building a relationship with consumers of hotel services means continuous monitoring of their behavior. The company can count on successful activity at the market and earning income through loyalty of consumers, partners and employees.

The constant process of tracking the company of information influences coming from the environment underlies the mechanism of forming the perception of the consumer. The consumer decides about interaction with the company based on the experience gained. Receiving a certain value (when making a purchase or receiving a service), the clients compare their expectations with the service that they have really received.

In the event when the consumer in a relationship with the enterprise sees an independent value, there will be a need for the marketing of the relationship and he will not buy similar services from competitors.

It is in the result of interaction with the customer of the services that the enterprise benefits. Consequently, the aforementioned fact determines the value of the client for the enterprise. The exchange of information between the staff and the consumer is useful for both of the sides: for enterprise and for the consumer, for which it is important not only timely and qualitative provision of the service, but also the polite and attentive attitude of the employees. Professional service, which turns in relies on experienced and friendly staff, the main reason is a prerequisite for the successful development of hotel and restaurant business. After all, creating and receiving positive emotions and interest in existing customers leads to repeated purchases and attraction of new customers at the expense of their recommendations.

The system of evaluating the results of marketing relations with consumers provides a comprehensive assessment and analysis of factors that affect their effectiveness and allow them to adapt quickly to the growing demands of the target market and reconcile consumer interests and claims.

In the hotel business the influence of the human factor on the client's impression of staying at the hotel is critical, as it is in this area that there is a constant direct contact of employees with consumers. In turn, the quality of the provision of services by employees depends on providing appropriate working conditions for them, development, motivation, as well as evaluation of work efficiency, etc.

Therefore, the application of marketing in the field of personnel management is a prerequisite for the successful operation of hotel enterprises and should be considered in the system of personnel marketing, since:

- introduction of marketing approach in personnel management at the enterprise provides a complex of interrelated measures;

- the system of personnel marketing is an integral part of personnel management at an enterprise;

- the personnel marketing system consists of separate functional elements intended for all stages of marketing activity.

After exploring and matching the needs and preferences of the consumer, the hotel can identify the main goals and priorities of building a relationship system, which is the basis of effective management and will contribute to the creation of strong 
long-term competitive advantages.

Conclusions and further prospects of the research. Marketing in the hotel industry has certain features associated with the specifics of the hotel industry. Therefore, the techniques of marketing research and development, functions, tasks of marketing techniques and elements of the marketing system used in the hotel industry should take into account the features of the hotel industry.

Enterprises of hotel business in modern conditions of management cannot achieve the set goals and priorities, be competitive and operate effectively without the active using of marketing and implementation of its concepts. The introduction of innovative marketing methods will ensure a high level of profitability of the hotel in a competitive environment, the formation of an appropriate image, satisfaction of clients' requirements regarding the volume, structure and quality of services, and will create conditions for stable business relations, a comprehensive solution to the commercial, organizational and social problems of the hotel company.

\section{References}

1. Berezin, I. S. (1999), Marketing i issledovanija rynkov [Marketing and market research], Russkaja delovaja literatura, Moscow, Russia.

2. Golubkov, E. P., (2003), Osnovy marketinga [The basics of marketing], Finpress, Moscow, Russia.

3. Bljek, Dzh. (2000), Jekonomika. Tolkovyj slovar' [Economy, Explanatory dictionary], Ves' Mir, Infra-M, Moscow, Russia.

4. Kotler, F. (1995), Osnovi marketinga [The basics of marketing], Biznes-kniga, Moscow, Russia.

5. Matsekha, D. S. and Buryi, S. A. (2014), "Marketing in the sphere of hotel and restaurant business and tourism", Visnyk Khmelnytskoho natsionalnoho universytetu, no. 5, pp. 43-47.

6. Pavlenko, I. H. (2013), "Client-oriented approach to managing the marketing interaction of the hotel", Biznes Inform, no. 9, pp. 347-354.

7. Romanenko, O. O. (2011), "Features of using the complex of marketing and its concepts at the enterprises of the hotel industry", Zbirnyk naukovykh prats Natsionalnoho universytetu derzhavnoi podatkovoi sluzhby Ukrainy, no. 1, pp. 490-494.

8. Skybinskyi, S. V., Ivanova, L. O. and Morhun, O. F. (2000), Marketynh hotelnykh posluh [Marketing of hotel services], Vydavnytstvo Lvivskoi komertsiinoi akademii, Lviv, Ukraine.

9. Frolova, V. Iu. (2014), "The concept of lateral marketing at a highly competitive market", Visnyk Donetskoho natsionalnoho universytetu. Seriia: Ekonomika i pravo, vol. 1, pp. 269-272.

10. Shmihelska, H. (2008), "Information technology in the logistics and marketing activities of retail enterprises", Visnyk Natsionalnoho universytetu «Lvivska politekhnika», no. 633, pp. 799-805.

\section{Список використаної літератури}

1. Березин, И. С. Маркетинг и исследования рынков / И. С. Березин. - М. : Русская деловая литература, 1999. - 416 с.

2. Голубков, Е. П. Основы маркетинга : учебник / Е. П. Голубков. - М. : Издательство «Финпресс», 2003. - $656 \mathrm{c.}$.

3. Блэк, Дж. Экономика. Толковый словарь / Дж. Блэк ; общая редакция д. э. н. И. М. Осадчая. - М. : «Инфра-М», Издательство «Весь Мир». - 2000. - 546 с.

4. Котлер, Ф. Основи маркетинга : пер. с англ. / Ф. Котлер - М. : «Бизнес-книга», «ИМАКросс Плюс», 1995. - 702 с. 
5. Мацеха, Д. С. Маркетинг у сфері готельно-ресторанного бізнесу та туризму / Д. С. Мацеха, С. А. Бурий // Вісник Хмельницького національного університету. - 2014. - № 5. T. 2. - C.43-47.

6. Павленко, І. Г. Клієнтоорієнтований підхід до управління маркетинговою взаємодією готелю / І. Г. Павленко // Бізнесінформ. - № 9. -2013. - С. 347-354.

7. Романенко, О. О. Особливості використання комплексу маркетингу та його концепцій на підприємствах готельного господарства / О. О. Романенко // Збірник наукових праць Національного університету державної податкової служби України. - № 1. - 2011. - С. 490 494.

8. Скибінський, С. В. Маркетинг готельних послуг / С. В. Скибінський, Л. О. Іванова, О. Ф. Моргун - Львів : Вид-во Львівської комерційної академії, 2000. - 246 с.

9. Фролова, В. Ю. Концепція латерального маркетингу в умовах висококонкурентного ринку / В. Ю. Фролова // Вісник Донецького національного університету. Серія: Економіка і право. - Вип. 1. - 2014. - С. 269-272.

10. Шмігельська, Г. Інформаційні технології в логістичній і маркетинговій діяльності роздрібних підприємств / Г. Шмігельська // Вісник Національного університету «Львівська політехніка». - 2008. - № 633. - С. 799-805.

\section{Бібліографічний опис для цитування:}

Kyryliuk, I. M. Features of the use of the marketing complex and its concepts at the enterprises of the hotel industry / I. M. Kyryliuk, O. V. Lytvyn // Науковий журнал «Економічні горизонти». - 2018. - № 1(4). - С. 91-98. 